\title{
INDONESIAN POLITICAL KLEPTOCRACY AND OLIGARCHY: A Critical Review from the Perspective of Islamic Law
}

\author{
Anita Marwing* \\ Faculty of Sharia, Institut Agama Islam Negeri Palopo, Indonesia \\ Email: anitamarwing@iainpalopo.ac.id
}

*Corresponding author

DOI: $10.21154 /$ justicia.2352

\begin{tabular}{l|l|l}
\hline Received: Dec 14, 2020 & Revised: Feb 16, 2021 & Approved: April 15, 2021 \\
\hline
\end{tabular}

Abstract: This study discusses corruption in the Indonesian political system from Islamic law, particularly regarding the Kleptocracy and political oligarchy. One of the most basic corruption causes comes from an internal personality factor, human's character; greedy and consumptive. Additionally, some factors also come from human external factors, namely the perpetrators' coercion because they are tied to a system. Corruption is carried out not only by individuals but also in cooperation/conspiracy between the bureaucracy and corporations and political parties. Elites called them Kleptocracy and political oligarchy. This research is descriptive qualitative research with an approach based on legal analysis. This research has found several things. First, corruption in the Indonesian political system can be categorized into acts of Ghulul (treachery), Risywah (Gratification/bribery), Khiyanah (Unfaithful), Sariqah (theft), and Hirabah (Grand Theft/ Robbery). Second. The strategy to eradicate corruption in an Islamic perspective can be carried out by imposing sanctions, including sanctions in the world's dimensions and the hereafter. This research encourages the strengthening of the socio-religious system, especially among religious leaders, as a preventive and curative form of handling corruption in the political system in Indonesia.

Penelitian ini membahas tentang korupsi dalam sistem politik Indonesia dalam perspektif hukum Islam, khususnya tentang kleptokrasi dan oligarki politik. Salah satu faktor penyebab korupsi yang paling mendasar adalah faktor kepribadian internal yang tamak, rakus dan konsumtif. Selain itu ada faktor yang memberi pengaruh lebih besar yakni faktor yang datang dari luar diri manusia, karena korupsi yang terjadi dewasa ini kadang adanya unsur keterpaksaan pelaku sebab terikat dalam sebuah sistem. Korupsi saat ini tidak hanya dilakukan oleh perorangan melainkan dalam bentuk kerjasama/persekongkolan antara birokrasi dan korporasi serta para elit-elit partai politik yang disebut dengan kleptokrasi dan oligarki politik. Penelitian ini merupakan penelitian kualitatif deskriptif dengan pendekatan berdasarkan legal hukum analisis. Dalam penelitian ini menemukan beberapa hal. Pertama, korupsi dalam dalam sistem politik Indonesia dapat dikategorikan dalam perbuatan Ghulul (Berkhianat), Risywah (Gratifikasi/suap), Khiyanah (Khianat), Sariqah (pencurian), dan Hirabah (Pencurian Besar/Perampokan). Kedua. Strategi pengentasan korupsi dalam perspektif Islam dapat dilakukan dengan pemberian sanksi yang meliputi sanksi berdimensi dunia dan akhirat. 
Anita Marwing, Indonesian Political Kleptocracy and Oligarchy: A Critical Review ...

Riset ini mendorong penguatan sistem sosio-religi terutama keadaan para pemuka agama sebagai bentuk preventif dan kuratif penanganan korupsi dalam sistem politik di Indonesia.

Keywords: Cleptocracy; Political Oligarchy; Islamic Law.

\section{INTRODUCTION}

Corruption is currently a prevalent word in Indonesia because people have not stopped talking about it decades ago. Corruption becomes increasingly popular when entering the reform era because so many public officials stumble over corruption cases and must be brought forward. Indonesia is an anti-corruption trade, but on the other hand, the corruption index is also high. With the current era of openness, publications on corruption are increasingly transparent, as evidenced by many reports about officials arrested for corruption through electronic media, newspapers, and even news on the internet/ cyber news ${ }^{1}$. This shows the role of the media as a means of monitoring corruption².

This is very beneficial for society because it can directly supervise corruption. After all, public interference will increase the power to eradicate corruption in this country. Besides, public awareness of corruption has an essential role in law enforcement ${ }^{3}$. However, the success or failure of handling corruption depends on the commitment and political will of all law enforcement officials who are responsible for handling it ${ }^{4}$. Unfortunately, corruption has spread and has taken root in law enforcement officials, including the Police, the Attorney General's Office, and the Court. This is a great challenge and requires hard work, even if necessary, to have an iron fist from the leader/ president ${ }^{5}$.

Many developing countries suffer under kleptocracy governments, namely governments controlled by many corrupters. They implement highly inefficient economic policies, rob their citizens of wealth, and use the proceeds to their advantage. This group tends to be close to corruption because they use power for their own or their group's interests ${ }^{6}$. Corruption has always been linked to abuse of authority/power in office. Abuse of authority often occurs because the supervisory

Markus H. Peranan Simarmata, "E-Government Dan Media Sosial Untuk Mewujudkan Budaya Transparansi Dan Pemberantasan Korupsi," Jurnal Integritas KPK 3, no. 2 (2017): 203-29.

2 Ita Suryani, "Peran Media Iklan Televisi Sebagai Media Kritik Kasus Korupsi (Studi Kasus Pada Iklan Konten Djarum 76 Versi Kontes Jin)," Jurnal Komunikasi 9, no. 2 (2015).

3 La Ode Bunga Ali and Muh. Sutri Mansyah, "Penafsiran Keterangan Palsu Dalam Persidangan Tindak Pidana Korupsi Kaitannya Kasus Obstruction of Justice: Kajian Putusan Nomor 14/Pid/Tpk/2015/ Pt.DKI," Justicia Islamica: Jurnal Kajian Hukum Dan Sosial 16, no. 1 (2019).

4 Paul M. Heywood, "Rethinking Corruption: Hocus-Pocus, Locus, and Focus. The Slavonic and East European Review," Innovations in Corruption Studies 95, no. 1 (January 2017): 21-48.

Rusdi Kantaprawira, Sistem Politik Indonesia (Bandung: Sinar Baru Algesindo, 1985), 10.

6 Daron Acemoglu, Thierry Verdier, and James A. Robinson, "Alfred Marshall Lecture Kleptocracy And Divide-And-Rule: A Model of Personal Rule," Journal of the European Economic Association 2, no. 2 (2004): 162-92. 
system does not work because of the cultural mentality problems assembled in the government bureaucratic structure ${ }^{7}$.

Based on the Indonesia Corruption Watch (ICW) records, during 2010-2017, at least 215 regional heads suspected corruption cases handled by the KPK, the police, and the prosecutor's office. ${ }^{8}$ These cases occur in various modes, such as game budgeting projects, budget approval bribes, corruption in the procurement of goods and services, licensing bribes, and case handling bribes. This figure is a high and alarming number'.

The reformed system in Indonesia has fertilized the democratization of the government system. However, the practice of political corruption is also increasingly prevalent among the political elite. The multiparty political system that forms a cartel party is one of the factors to increase political corruption. Cartel parties create a cooperation system that can maintain and regulate the country following their groups' interests, especially finding funding sources originating from state finances. The existence of closeness and financial strength will allow the party to control the government's strategic position ${ }^{10}$. This condition does not only happen in the central and regional government but even at the village level ${ }^{11}$. This practice of power is shared ${ }^{12}$. Kleptocracy practices usually occur because power has a crucial role in shaping the nature of political competition and the long-term prospects for democratization. In contrast, the role is controlled by an oligarchic group consisting of a group of rulers based on family closeness and wealth ${ }^{13}$.

Political corruption has a more structured system than corruption because political corruption is used to benefit political parties. The crimes of political corruption actors are controlled and protected by party elites who control all aspects of state life ${ }^{14}$. Political elites influence to be responsible for political corruption cases that may occur through control of state institutions; the executive, legislative, and

7 Jody LaPorte, "Foreign versus Domestic Bribery: Explaining Repression in Kleptocratic Regimes," Comparative Politics 50, no. 1 (October 2017): 83-102.

8 Marulak Pardede, "Aspek Hukum Pemberantasan Tindak Pidana Korupsi Oleh Korporasi Dalam Bidang Perpajakan (Legal Aspect of Eradication of Corruption Criminal Act in Taxation)," Jurnal Penelitian Hukum De Jure 20, no. 3 (2020): 335-61.

9 Indonesia Corruption Watch, “Outlook Korupsi Politik 2018: Ancaman Korupsi Di Balik Pemilu 2018 Dan 2019" (Jakarta, 2018).

10 Patricia Gloster Coates and Linda Quest, "Kleptocracy: Curse of Development," International Social Science Review 8, no. 1 (2015): 3-19.

11 Haris Samsuddin, Cakti Indra Gunawan, and Cahyo Sasmito, "Membongkar Relasi Kekuasaan Oligarki Di Kota Batu: Studi Kasus Penyalahgunaan Kekuasaan Dalam Pemberian Keringanan Pajak Dan Korupsi Kebijakan Pt Bwr," Jurnal Ilmu Administrasi XVI, no. 2 (2019): 210-27.

12 Johan Satriajaya, Lilik Handajani, and I Nyoman Nugraha Ardana Putra, "Turbulensi Dan Legalisasi Kleptokrasi Dalam Pengelolaan Keuangan Desa," Jurnal Akuntansi Multiparadigma JAMAL 8, no. 2 (2017): 227-429.

13 LaPorte, "Foreign versus Domestic Bribery: Explaining Repression in Kleptocratic Regimes."

14 Listiyono Santoso, Dewi Meyriswati, and Ilham Nur Alfian, "Korupsi Dan Mentalitas: Kendala Kultural Dalam Pemberantasan Korupsi Di Indonesia," Masyarakat, Kebudayaan Dan Politik 27, no. 4 (2014): 173-83. 
judiciary ${ }^{15}$. This is happened because of the cooperation system of political parties, which prioritized their common interests to obtain state financial resources. The group is known as the cartel party.

The KPK is a state institution formed to increase the effectiveness of eradicating corruption independently and unbound from the influence of any power in carrying out its duties and authorities ${ }^{16}$.

This commission was established based on the Law of the Republic of Indonesia Number 30 of 2002 on the Corruption Eradication Commission. In carrying out its duties, the KPK is guided by five principles: legal certainty, transparency, accountability, public interest, and proportionality. Then with the Corruption Eradication Commission's periodic formation and the making of the Corruption Law that underwent revisions and finally government regulations RI Law number 20 of 2001 amendments to the Republic of Indonesia Law number 31 of 1999 eradication of corruption ${ }^{17}$.

In the Republic of Indonesia's laws, officials' and politicians' corrupt behavior is also explicitly explained in the al-Qur'an as a form of public betrayal because the public mandate is not carried out correctly ${ }^{18}$. As in Qs, Ali Imran [3]: $161^{19}$.

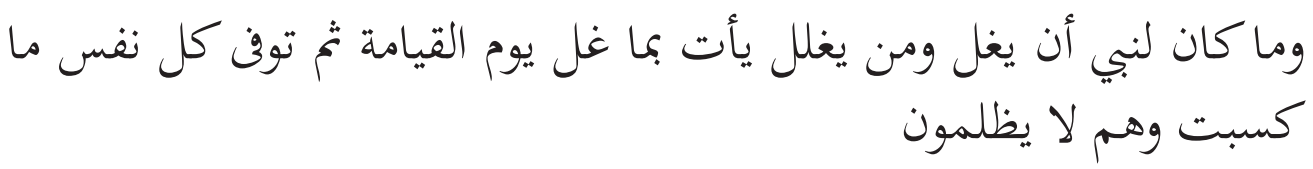

"It is impossible for a Prophet to betray the spoils of war. Whoever betrayed the spoils of war, then on the Day of Resurrection, he will come with what he betrayed. Each person will be given retribution for what he did with (retribution) accordingly, while they are not persecuted".

Based on the above, the Kleptocracy and political oligarchy ${ }^{20}$ are part of the Indonesian political system discussion, which is interesting to understand and the legal provisions for these activities in Islamic law. With these considerations, the researcher tries to raise this research using a normative juridical approach with the title "Kleptocracy and Political Oligarchy in the Perspective of Islamic Law."

This research is a qualitative type using a juridical-historical approach. Sources of legal materials include primary and secondary legal materials. Primary legal materials consist of statutory regulations, official records, minutes of legislation making, and judges' decisions ${ }^{21}$.

\footnotetext{
15 Herri Junius Nge, “Oligarki Partai Politik Dalam Rekrutmencalon Kepala Daerah (Studi Kasus Munculnya Calon Tunggal Pada Pemilihan Kepala Daerah Kabupaten Landak Tahun 2017)," Jurnal Academia Praja 1, no. 1 (2018): 59-84.

16 Budi Hatees, Ulat Di Kebun Polri Dinamika Penegakan Keadilan Hukum) (Jakarta: Raih Asa Sukses, 2013$), 85$.

17 H. Juni Sjafrien Jahja, Pemberantasan Tindak Pidana Korupsi (Jakarta: Fokus Media, 2008), 8.

18 Muhammadiyah dan Nahdaltul Ulama (NU), Korupsi Itu Kafir (Jakarta: Mizan, 2010).

19 Departemen Agama RI, Al-Qur'an Dan Terjemahannya (Bandung: J-Art, 2004), 71.

20 Abdul Wahid, “Kolaborasi Kleptokrasi Birokrasi Dan Korporasi," Jurnal Yurispunden 1, no. 1 (2018): 1-16.

21 Peter Mahmud Marzuki, Penelitian Hukum (Jakarta: Prenada Media Group, 2011), 141.
} 
The secondary law material contains the basic principles of law science and highly qualified scholars' classical views. In this case, the secondary legal materials used include Scientific books in law, Papers, Scientific journals, and Scientific articles. Sources of information in this research include informants, namely individuals, who have extensive knowledge, authority, and position in society, and experts as sources on Corruption in the Indonesian Political System.

The research implementation procedure is technically carried out by data collection stages, data reduction, data presentation, and data analysis ${ }^{22}$. The analysis uses Content Analysis. ${ }^{23}$ The analysis procedure is first to reduce the data, second, to classify it in the main form found, then to analyze it by giving meaning in each of the primary studies carried out. The content analysis method seeks to see the consistency of meaning in a text described in structured patterns. It brings researchers to an understanding of the value system behind the text.

This study's results are expected to become a guide in preventing the practice of kleptocracy and oligarchic activities, especially in government, from the perspective of Islamic law. It is also expected that with an understanding of Islamic law, society in general and actors of the kleptocracy and oligarchy realize that this practice is a sin and harms society.

\section{CORRUPTION ERADICATION STRATEGY IN INDONESIAN POLITICAL SYSTEM}

Eradicating corruption in Indonesia's current political system is not easy because it has become a culture en-grained at all levels of society. After all, the characteristics of corruption in Indonesia are incredibly complex and systematic. Thus, it takes efforts to eradicate corruption systematically, integrative, comprehensive, and focused. Following the Law mandate to address corruption, political corruption, which is increasingly endemic, cannot be overcome by continuously arresting and imprisoning politicians ${ }^{24}$. The underlying reason for this type of corruption's continued occurrence is a failure to create a political system with integrity ${ }^{25}$.

The Corruption Eradication Commission (KPK), as a state institution focused on eradicating corruption, is increasingly aggressive in arresting and imprisoning corrupt officials or politicians in this country. It has not succeeded in completely eradicating corruption because an indicator of the success of eradicating corruption is actually when there are fewer officials and politicians

22 Elliott Jane, Using Narrative in Social Research: Qualitative and Quantitative Approaches (London: Sage Publication Ltd, 2005), 145.

23 Amir Hamzah, Metode Penelitian Kepustakaan (Malang: CV. Literasi Nusantara Abadi, 2020), 62.

24 Italo Pardo, "Who Is Corrupt? Anthropological Reflections on The Moral, The Criminal and The Borderline," Human Affairs 23 (2013): 124-47.

25 David Kennedy, “Anarchism, Shooling, and Democratic Sensibility," Stud Philos Educ, 2016, 1-18. 
caught in corruption cases. Therefore, prevention strategies are the essential thing in eradicating corruption besides arresting. The rampant corruption rampant is the Corruption Eradication Commission's enemy and other state institutions or NGOs, and all Indonesian people. In this discussion, the author will describe several strategic plans to prevent corruption in the Indonesian political system, as an effort to eradicate the following are:

\section{Anti-Corruption Education}

Nowadays, anti-corruption education should be the essential part to get attention because corruption has now entered all aspects of society. Particularly for political corruption, the education route will be an excellent solution to prevent corruption by preparing a generation of intelligent people with integrity. Going through good education, new political cadres will be born and become political actors expectedly without any corruption involved. This anti-corruption education can be given from an early age to adulthood, with several education levels: a. anti-corruption education at home; b anti-corruption education in schools; $c$. anti-corruption education in higher education.

\section{Religious Path}

A way to prevent corruption nowadays is through the religious path because it is an instrument or a moral source for every individual religious community. The State of Indonesia is a religious country, and politicians or officials, as state administrators, are religious people. This step is expected to be a solution to the moral crisis that has hit this nation and has resulted in high corruption cases.

To apply it, several steps must be taken. Firstly, encourage religious leaders or religious institutions to issue fatwas and opinions on corruption and moral sanctions for corruption actors. Secondly, religious leaders continuously encourage their followers to live up to their respective religions because there is no religious teaching in this country justifying to do corruption. Thirdly is to optimize the potential of places of worship owned by each religion as a means of campaigning for anti-corruption behavior through religious activities. ${ }^{26}$

\section{Legal Approach}

Eradicating corruption can only be carried out if the law enforcement is carried out firmly and indiscriminately. Therefore prosecutors, judges, and the police must have the courage to take any decisions against corruption ${ }^{27}$. Our current legal system is still considered weak because it still provides room for corruption to avoid legal traps, and government policies are still slow to amputate

26 Muhammadiyah dan Nahdaltul Ulama (NU), Korupsi Itu Kafir (Jakarta: Mizan, 2010), 56.

27 Mark L. Wolf, “The World Needs an International Anti-Corruption Court," Daedalus 147, no. 3 (2018): 144-56. 
acts of corruption. The following are steps to eradicate corruption through a traditional approach:

a. Encouraging the government and the legislature to revise anticorruption laws, expand the meaning of corruption, and impose heavier sanctions than before for corruption perpetrators.

b. Planning a rational and proportional budget formulation in each budget line for each state administrator.

c. Encouraging executive, legislative and judicial governments, implementing a transparent, accountable, and responsive government system to develop people's aspirations.

d. Encouraging the executive, legislative, and judiciary governments and leaders or members of political parties not to hold concurrent positions.

The selection system for law enforcers should prioritize integrity and quality to create law enforcement free from corruption ${ }^{28}$.

\section{Political Approach}

One of the causes of political corruption is the high $\cos ^{29}$ of politics, ranging from funding for nominated political party candidates to financing at the campaign stage. There is an element of compulsion for the elected candidates to return the capital spent during political contestation. Therefore, improvements in the electoral and party political system will be an effective solution to prevent corruption. Here are some forms of improvement that must be conducted:

a. Political parties must equip party members/cadres with clear modules and regeneration levels to support members/cadres with leadership qualities and skills before engaging in political contestation.

b. Political parties must conduct integrity tests on members/cadres who will advance in political contestation.

c. Political parties must have the courage to decide not to nominate members/cadres who have a terrible track record. Moreover, a former corruption convict, despite his high popularity.

d. The system for recruitment and candidacy of candidates for officials, both executive and legislative, must be based on merit and the quality of members/cadres built up through party regeneration levels ${ }^{30}$.

e. Political parties no longer use political dowries to support members/ cadres participating in the election because the State has funded

28 Muhammadiyah dan Nahdaltul Ulama (NU), Korupsi Itu Kafir, 2010, 60.

29 Barney Warf, “Global Geographies of Corruption," GeoJournal 81, no. 5 (2016): 657-69.

30 "Disampaikan Dalam Materi Kelas Politik Cerdas Berintegritas," 2017. 
Anita Marwing, Indonesian Political Kleptocracy and Oligarchy: A Critical Review ...

political parties. It is also expected that party members/cadres who will advance in political contestation will no longer seek funding sources from corporations that will include their pragmatic interests in political policy when a candidate has been elected in the election, resulting in a Kleptocracy

\section{Public Participation}

Community involvement greatly influences the corruption eradication agenda because corruption eradication is public goods or public property. If corruption is reduced in the State, then automatically, corruption is also reduced for every citizen. Currently, public participation in eradicating corruption is minimal, while state administrators' corrupt acts always worry about corruption. There are still those who ask why we should be involved in eradicating corruption, while we are not members of the KPK, not the police, not prosecutors and judges. As a form of public participation, the author will give one example, based on the shared awareness that corruption is the enemy of all of us, the civil society community in South Sulawesi from academics, NGOs, journalists, and public figures feels that they have an interest in forming an institution concerning about corruption issues.

On December 26, 1998, the South Sulawesi Anti Corruption Committee (ACC) establishment was declared. As a society component in building an anticorruption popular movement, ACC requires a strong organization and specific capacities in carrying out its activities. Various factors influence the ACC's performance as an element of the anti-corruption movement. These factors can be identified from the relationships between the political, social-cultural, and economic spheres that influence each other.

ACC has a vision, the realization of civil society is aware and critical of the phenomenon of corruption, and the realization of a state administration meets the people's basic needs and rights in a transparent and accountable manner. Additionally, the mission is to encourage transparency in the making and implementation of public policies, directly monitoring every process of making and implementing public policies, encouraging the completion of corruption cases, and building an anti-corruption culture by encouraging the emergence and development of the anti-corruption popular movement.

Currently, ACC Sulawesi is actively campaigning anti-corruption movements to the people of South Sulawesi, especially in Makassar City, then conducting anti-corruption education to remote districts/cities in South Sulawesi by targeting schools starting from Elementary School (SD)/ other equal education institutions, up to Senior High School (SMA)/ other equal education institutions, and also 
universities and student study groups as a measure to prevent corruption. Moreover, the movement of control and guarding against corruption cases has reached the stage of solving cases or court decisions.

This is an achievement of public involvement in eradicating corruption and recommended for every region in Indonesia to do similarly. The anti-corruption movement is increasingly being carried out until our country is free from corruption.

\section{Reward And Punishment}

The application of rewards and punishments can be one of the community's and state administrators' motivations to prevent corruption. For example, giving rewards to the public and other state administrators who are actively involved in the prevention and eradication of corruption crimes, on the other hand, provides appropriate penalties for state officials who have a poor work ethic or other corrupt traits small scale.

\section{CATEGORIZATION OF CORRUPT BEHAVIOR IN INDONESIAN POLITICS: AN OVERVIEW OF ISLAMIC LAW}

In the perspective of Islamic law, corrupt behavior in Indonesian politics can be categorized as deviant as follows:

a). Ghulul (Betrayal)

Ghulul is terminologically defined as taking something and hiding it in its treasure. Furthermore, it developed into fraudulent and treasonous acts against other assets, such as embezzlement against baitul mal assets, Muslims' common property, joint assets in business work, state assets, and others ${ }^{31}$. Rasulullah SAW emphasized in his hadith the meaning of Ghulul, namely the action of someone who takes something or income outside of his predetermined salary. It can be concluded that Ghulul's behavior is part of an attitude of corruption because Ghulul is also an act of an official empowered but misused for personal gain.

\section{b). Risywah (Gratuities/Bribes)}

Risyawah and bribery in a political context are separated. Risyawah has a broader meaning than bribery because risyawah can occur in two directions: when people try to give something to the ruler to get their benefit, then it is accepted by the authorities as intended by the giver, in the context of criminal law ${ }^{32}$ is referred to as Gratification. On the contrary, it is also if the ruler gives something to the people to maintain his power. The first example is the provision of transport cost

31 M. Muhaki, "Problem Delik Korupsi Dalam Hukum Pidana Islam," Jurnal Studi Islam: Pancawahana 12, no. 2 (2017): 22-38.

32 T. Andiko, "Sanksi Bagi Pemberi Dan Penerima Gratifikasi Perspektif Hukum Pidana Islam," Qiyas: Jurnal Hukum Islam Dan Peradilan 1, no. 1 (2017): 117-32. 
to voters, compensation for work costs, or compensation for leaving the intended work, and giving zakat or alms or money politics specifically to buy voting rights to make the recipient choosing a particular candidate. Bribes can only occur in one direction, namely a giving from the people to the authorities to influence the decisions issued.

\section{c). Khiyanah (treacherous)}

Khiyanah generally means not keeping promises. In politics, Khiyanah abuses the mandate given by the people in the form of power or government ${ }^{33}$. In the Indonesian political system, this mandate is obtained through general elections and is open to anyone who wishes to occupy a government position. Thus, whoever gets the position through the general election should also carry out that mandate in general because the people who elect him expect prosperity in their lives. Nevertheless, if they do corrupt by abusing their power (Khiyanah), they have violated their rights and obligations, the rights of humans, or the people they lead and violate their obligations to Allah. Both of them will be asked they are accountable in the Hereafter. Allah SWT calls on every human being who has a position to take responsibility for the position correctly, as in his words in the Al-Qur'an Surah An-Nisa (4) Verse 58 and Al-Qur'an Surah Al-Ma'rij (70) verse 32-35 as follows :

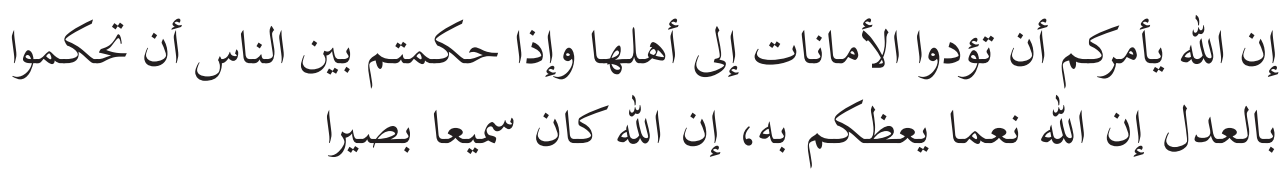

"Allah told you to convey the message to those who deserve it." 34

In Islamic principles, the public mandate must be carried out based on the principle of public benefit, as is the Fiqh Rule as stated as follows: "It is not a leader who takes care of Muslims than does not really (think about their fate) and makes them prosperous like he is serious about thinking about and prospering himself, except will not go to heaven with them Muslims."

\section{d). Sariqah (Stealing)}

In Islam, stealing is taking the property or property of another person. In contrast, in the context of Islamic politics, it views the essence of being the same as corruption in general, as an action taken by public officials by misusing their authority to enrich themselves. In contrast, the assets they take are public assets ${ }^{35}$. Moreover, public assets are entrusted to him to be managed as they should be

33 K. Harto, “Pendidikan Anti Korupsi Berbasis Agama. , 20, No.1, (2014): 121-138.," Intizar 20, no. 1 (2014): 121-38.

34 Departemen Agama RI, Al-Qur'an Dan Terjemahannya, 124.

35 E. Yuhermansyah and Z. Fariza, "Pidana Mati Dalam Undang-Undang Tindak Pidana Korupsi (Kajian Teori Zawajir Dan Jawabir)," Legitimasi: Jurnal Hukum Pidana Dan Politik Hukum 6, no. 1 (2017): 156-74. 
used for public interests. However, when public assets are used for personal gain or enrich themselves as public officials, they are categorized as sariqah. According to public needs, humans appointed as rulers or public officials only function as facilitators to manage and distribute public assets. This Islamic principle seeks to overhaul the rulers' feudal culture, who think that the people's property can be used according to its will. The authorities may not use property obtained from the people for personal gain or self-enrichment because that means sariqah.

Allah SWT then confirmed to humans in QS. Al-Maidah (5): 38 as follows:

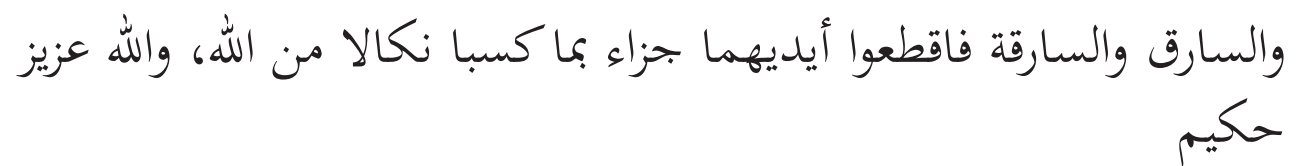

"Men who steal and women who steal, cut off both hands (as) retribution for what they do and as torment from Allah. and Allah is Mighty, Most Wise".

From the above verse, we can conclude that sariqah (stealing) is prohibited in Islam, and the law is Haram.

e). Hirabah (Robbery)

The meaning of hirabah is to fight against Allah, and His Messenger as Allah has said as follows QS Al-Maidah [5] ${ }^{36}$. Fakhr Al-Din Al-Razi interpreted hirabah as violating the commandments of Allah and His Messenger. Thus, the verse could be interpreted as follows: "Verily retribution for those who violate the orders of Allah and His Messenger," Hirabah includes qath'u al-thariq (roadblocking). qath'u al-thariq is taking other people's property openly and violently, whether by killing or not. Therefore, qath'u al-thariq is interpreted as al-sariqah al-qubra (great robbery). Therefore, the law is more significant than sariqah ${ }^{37}$.

Based on the explanation of the verse above, we can also conclude that the behavior of the hirabah is a form of corruption in the context of political corruption. This act both causes damage or paralysis of the public order and threatens property and human life. An example of the current hirabah is corruption carried out on a large scale or in large numbers by cartel parties or political corporations, because corruption, in this case, is not only aimed at enriching themselves but also enriching other people, or groups they form in a political system in order to maintain their power. Suppose it is drawn in the meaning of qath'u al-thariq. In that case, corruption is the same as hirabah because both cause terrible damage that must be borne by the community, such as damage to the environment, not properly upholding the law, and ineffective service of the State apparatus to the community.

36 Muhammadiyah dan Nahdaltul Ulama (NU), Korupsi Itu Kafir, 2010, 125.

37 Muhammadiyah dan Nahdaltul Ulama (NU), 132. 
This then has an impact as a threat to the lives and property of the community because corruption causes people to starve, ignorance, and become vulnerable to disease due to insufficient community income, so they are unable to reach nutritious food and adequate treatment ${ }^{38}$.

Therefore, the legal conclusion that we can draw is that corruption or hirabah is a haram act in Islam and is also a major sin because the losses and impacts caused are also huge.

Considering the massive acts of corruption committed by public officials in every position they occupy is in the form of abuse of their authority and the use of State property and assets for personal gain. Therefore, it is necessary to impose sanctions on criminal acts of corruption, either through conventional criminal law approaches or Islamic law, or the integration of both. In jinnayah figh, corruption has elements of maliyyah crime. According to the value of corruption, losses, and impacts, legal sanctions for these crimes can be applied, ranging from the lightest legal sanctions to the most severe ones. One of the sanctions instruments that can be applied to perpetrators of corruption is $T a^{\prime} z i r$ as Islamic law. $T a^{\prime} z i r$ is punishment for convicts that are not specified in the texts of the Qur'an and hadith. The law of $\mathrm{Ta}^{\prime}$ zir is imposed to teach convicts so that they do not repeat the crimes they have committed. Thus, the law is called "uqubah mukhayyarah" or "Optional Punishment." There are two types of Jarimah which are subject to $t a^{\prime} z i r$ law, namely, Jarimah as a subject to the Had and Qhisash laws if one of the elements and pillars are fulfilled; and Jarimah as not a subject to the Had and Qhisash laws if the elements and pillars are not fulfilled. For example, treason against the given mandate, burning, bribery, and others. In corruption, three elements can be considered to determine the law: confiscation of other people's property, betrayal, or abuse of authority and cooperation in crime. These three elements are prohibited in Islam, so determining $t a^{\prime} z i r$ can be classified according to the severity and lightness or magnitude of corruption and the impact it caused ${ }^{39}$.

The following are some of the sanctions that can be given to actors doing corruption based on the classification of Jarimah, namely an act prohibited by syara' and the law determined by Allah either in the form of sanctions having explicit provisions or not.

1). Punishment in the World for the actors of Corruption

Punishment in the World given to the actors of Corruption refer to the size of the material loss. The smaller the loss, the more minor the penalty, and the more significant the loss, the worst penalty. In Islamic law, the provision of legal

38 Muhammadiyah dan Nahdaltul Ulama (NU), 132.

39 Muhammadiyah dan Nahdaltul Ulama (NU), Korupsi Itu Kafir, 2010, 33. 
intervention, which is a Punishment in the World, can take several forms: 1) Non-physical legal sanctions in the form of dismissal, fines, and confiscation; 2) Physical, legal sanctions, among them, are a) cutting off hands for doing hirabah and qath'u al-thariq which only rob property without killing; b) Cut off the hands and feet for doing hirabah and qath'u al-thariq repeatedly; c) Killed and crucified for doing qath'u al-thariq \by robbing property and resulting in death, for example, corruption of disaster management funds resulting death for the victims; and d) Evicted and exiled or imprisoned for life for doing hirabah and qath'u al-thariq by causing feared to threaten the safety of others, such as corruption of reforestation funds resulting in floods or landslides ${ }^{40}$.

The third is Social sanctions. The process of giving social sanctions refers to the word of Allah SWT. (Surah Al-Maidah [5] verse 42) “They are people who like to hear fake news, eat a lot of what is haram. If they (the Jews) come to you (to ask for a verdict), then decide (the matter) among them, or turn away from them; if you stay away from them, then they will not harm you in the slightest. Furthermore, if you decide their case, then decide (that matter) among them somewhat, Allah loves those who are in just ${ }^{41}$.

Using corrupt assets is the same as using haram property because social giving in isolating the actors of corruption from society can be applied. The act of ex-communication that can be taken is by not selecting actors of corruption as formal leaders, either as representatives of the people, such as the president, governor, district head, and members of the DPR, DPD, and DPRD. Moreover, they do not recognize them as non-formal leaders such as religious leaders or community leaders. Then, his testimony is not received, such as the testimony in legal evidence in court, testimony in the itsbat (determination) at the beginning of Ramadan, and other testimonies. The perpetrator of corruption is a person who had betrayed ${ }^{42}$ 4) Moral Sanctions. Moral sanctions are also significant to be applied to actors of corruption. The goal is that Muslims or religious communities keep reminding them that corruption is an act in contrast to religious morals. The following are some of the moral sanctions that can be punished to the actors of corruption:

a) The body is not obscured

Not praying for the corpses of the actors of corruption refers to the hadith of the Prophet Muhammad as follows: "Has told us Musaddad that Yahya bin Sa'id and Bisyr bin Al Mufadhdhal have told them from Yahya bin Sa'id from Muhammad bin Yahya bin Hibban from Abu Amrah. from Zaid bin Khalid Al

40 Muhammadiyah dan Nahdaltul Ulama (NU), 135.

41 Departemen Agama RI, Al-Qur'an Dan Terjemahannya, 162.

42 Muhammadiyah dan Nahdaltul Ulama (NU), Korupsi Itu Kafir, 2010, 137. 
Anita Marwing, Indonesian Political Kleptocracy and Oligarchy: A Critical Review ...

Juhani that a friend of the Prophet sallallaahu 'alaihi wasallam died during the Khaibar war. Then the companions told this to the Prophet Muhammad. He said: "Pray for your friends!" Then, the people's facial features changed because of that. Then he said: "Verily, your friends have committed treason in the way of Allah." Then we checked the goods, and we found Jewish pearls that were not worthy of two dirhams. (HR. Abu Da'ud) ${ }^{43}$.

b) The stigmatization of despicable people against actors of corruption

This affects individuals who commit corruption and affects the family, who also enjoy the results of corruption. This is as in the word of Allah SWT in (QS. Al-mutaffifin [83] verse 1:

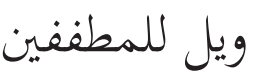

"Big accident for those who cheat."

The stigmatization of the perpetrators of corruption will encourage family control over their families in vulnerable positions to corrupt behavior. This refers to:

2). Hereafter Sanctions

Islamic teachings cover regulating all aspects of human life and regulating human life in the world to the hereafter, including the rule of law for human actions. Every human good and evil will get a reward in this world and the hereafter. In the context of corruption, there are several laws that actors of corruption will accept in the afterlife, as follows:

a). Corruption prevents the actors from gaining heaven

In Islamic teachings, the actors who commit corruption will get punished through his actions, becoming a barrier for him to enter heaven because the property he earned is referred to by $A l$-suht as said in the hadith of the Prophet Muhammad, "to Abdullah bin Uthman bin Khutsaim from Abdurrahman bin Sabith from Jabir bin Abdullah that the Messenger of Allah -peace and prayer of Allah be upon him- said: “O Ka'b bin 'Ujrah there will not be any flesh that grows from haram food" (Narrated by Al-Dharimi ).

b) Corruption causes the actors to get rewarded with hell

Doing Corruption causes a person to get rewarded with hell. This is as stated in the hadith of the Prophet Muhammad:

"Having told us, Abdurrazaq had told us that Ma'mar from Ibn Khutsaim from Abdurrahman bin Sabith from Jabir bin Abdullah, indeed the Prophet sallallaahu 'alaihi wasallam said to Ka'b bin' Ujroh, "May Allah protect you from the rule of ignorant people," (Ka'b bin 'Ujroh Radliyallahu'anhu) asked, what is the

43 Abu Daud Sulaiman bin Alasyas Assubuhastani, Sunan Abu Daud, vol. 2, 2710 (Bairut-Libanon: Darul Kutub, 1996), 272. 
government of a fool? (Rasulullah sallallaahu 'alaihi wasallam) said: "Namely the leaders of the countries after me who do not follow my instructions and also do not walk by my sunnah, whoever justifies them with their lies and helps them for their piety then he is not my group, and I am also not in their group, they will not come to me on my ears, whoever does not justify them for their lies, and does not help them because of their piety then they are my group, and I am also their group, and they will come to me on my ears. O Ka'b bin 'Ujroh fasting is a shield. All giving extinguishes the fire of hell, and prayer is an offering. Alternatively, he says a light. O Ka'b bin Ujroh actually will not enter the heaven of flesh that grows from things causing Allah's anger (haram), and hell is the most appropriate for, $\mathrm{O}$ $\mathrm{Ka}$ 'b bin 'Ujroh man is fasting with two conditions; namely he is sold himself later, and he sets him free, or he sells himself, and then he destroys himself" 44 .

c). The treasures of corruption will burden the actors on the Day of Judgment In Islamic teachings, the wealth obtained will be a burden in the hereafter because it is classified as ghulul. As stated in the hadith of the Prophet Muhammad: Translation:

"Having told us, Abu Bakr bin Abi Syaibah and 'Amru An Naqid and Ibn Abi Umar while the lafadz is from Abu Bakr, they said; had told us Sufyan bin Uyainah from Az Zuhri from 'Urwah from Abu Humaid As Sa'idi he said, "Rasulullah sallallahu 'alaihi wasallam employed a man from the tribe of Al Asad named Ibn LutbiyahAmru and Ibn Abu 'Umar said- to collect assets as close as (zakat). When depositing the zakat that he had collected, he said, "This Zakat I give to you, and this is a gift to me." Abu Humaid said, "Rasulullah sallallahu 'alaihi wasallam then gave a speech on the pulpit, after he praised and praising Allah, he conveyed: "There is an officer whom I commissioned to collect zakat, he said, 'This Zakat that I give to you, and this is giving people to me.' Why doesn't he just sit at the house of his mother and father waiting for someone to deliver gifts to him? By Allah, whose soul Muhammad is in His hands, none of you embezzle zakat when he is assigned to collect it. However, on the Day of Resurrection, he will carry the camel he darkened. It groans around its neck, or the cow (ox) mooing, or the goat moaning. "Then he raised his hands so that we saw the white of his armpits. Then he said: 'O Allah, I have told you.' He said it twice. "Having told us, Ishaq bin Ibrahim and Abd bin Humaid both said; 'have told us, Abdurrazaq has told us Ma' mar from Az Zuhri from 'Urwah from Abu Humaid As Sa'idi he said, "Prophet Muhammad once appointed Ibn Lutbiyah, namely a man from Asd (to become an employee), to collect zakat, then he came to the Prophet sallallaahu' alaihi wasallam and handed over the zakat he had collected, then he said, "This is zakat. that I give to you, and this is what people gave me. "Then he said: "Why doesn't he just sit at the house of his mother and father while waiting to see if someone wants to deliver a gift to him or not." After that, the Prophet sallallaahu 'alaihi wasallam stood up to speak. "Then he mentioned the hadith like Sufyan." (Narrated by Muslim)45.

44 Muhammadiyah dan Nahdaltul Ulama (NU), Korupsi Itu Kafir, 2010, 139.

45 Abu Husain Muslim bin Hajjaj Alqusyairi Annaisaburi, Kepemimpinan (Bairut-Libanon: Darul Fikri, 1993), 190. 
Anita Marwing, Indonesian Political Kleptocracy and Oligarchy: A Critical Review ...

The several types of sanctions above and the arguments that strengthen how corruption should be punished can have a deterrent effect on the actors of corruption. Islam has guided through the Qur'an and Hadith as guidelines for humanity. Whoever has been negligent of those instructions means that humans have denied or even violated Allah's orders and his apostles so that they have become Kafirs. Likewise, with corruption, an act violating Allah Almighty and Kufr's orders for pleasure, corruption is categorized as Kafir.

\section{CONCLUSION}

Islam has a specific view and understanding of the various forms of corruption, namely, Ghulul (betrayal), Risywah (bribery), Khiyanah (treacherous), Sariqah (robbery), and Hirabah (Big Robbery). This Islamic view, of course, will also affect the law of corruption. The definition and type of law need to be conveyed to the broader community. Religious leaders also have a role and duty to raise awareness and understand Muslims about the dangers of corruption.

The strategy of eradicating corruption from an Islamic perspective can be carried out by imposing sanctions, including world sanctions such as nonphysical sanctions, corporal punishment; social sanctions; and moral sanctions. The sanctions in the hereafter are sanctions that will be obtained by the actors in the hereafter, such as corruption, preventing the actors from getting to heaven; Corruption causes the actors to be rewarded with hell; and the treasures of corruption will burden the actors on the Day of Resurrection.

\section{REFERENCES}

Acemoglu, Daron, Thierry Verdier, and James A. Robinson. "Alfred Marshall Lecture Kleptocracy And Divide-And-Rule: A Model of Personal Rule." Journal of the European Economic Association 2, no. 2 (2004): 162-92.

Alasyas Assubuhastani, Abu Daud Sulaiman bin. Sunan Abu Daud. Vol. 2. 2710. Bairut-Libanon: Darul Kutub, 1996.

Ali, La Ode Bunga, and Muh. Sutri Mansyah. “Penafsiran Keterangan Palsu Dalam Persidangan Tindak Pidana Korupsi Kaitannya Kasus Obstruction of Justice: Kajian Putusan Nomor 14/Pid/Tpk/2015/Pt.DKI." Justicia Islamica: Jurnal Kajian Hukum Dan Sosial 16, no. 1 (2019).

Annaisaburi, Abu Husain Muslim bin Hajjaj Alqusyairi. Kepemimpinan. BairutLibanon: Darul Fikri, 1993.

Andiko, T. "Sanksi Bagi Pemberi Dan Penerima Gratifikasi Perspektif Hukum Pidana Islam." Qiyas: Jurnal Hukum Islam Dan Peradilan 1, no. 1 (2017): 117-32. Coates, Patricia Gloster, and Linda Quest. "Kleptocracy: Curse of Development." International Social Science Review 8, no. 1 (2015): 3-19. 
Departemen Agama RI. Al-Qur'an Dan Terjemahannya. Bandung: J-Art, 2004. Hakim, Nugraha Ikhsanul. "Pembuktian Terbalik Dalam Tindak Pidana Korupsi Ditinjau Dari Fiqh Jinayah (Studi Di Pengadilan Tindak Pidana Korupsi Palembang)." Skripsi, UIN Raden Fatah, 2019.

Hamzah, Amir. Metode Penelitian Kepustakaan. Malang: CV. Literasi Nusantara Abadi, 2020.

Harto, K. “Pendidikan Anti Korupsi Berbasis Agama. , 20, No.1, (2014): 121-138." Intizar 20, no. 1 (2014): 121-38.

Hatees, Budi. Ulat Di Kebun Polri ( Dinamika Penegakan Keadilan Hukum). Jakarta: Raih Asa Sukses, 2013.

Heywood, Paul M. "Rethinking Corruption: Hocus-Pocus, Locus and Focus. The Slavonic and East European Review." Innovations in Corruption Studies 95, no. 1 (January 2017): 21-48.

Indonesia Corruption Watch. “Outlook Korupsi Politik 2018:Ancaman Korupsi Di Balik Pemilu 2018 Dan 2019." Jakarta, 2018.

Jahja, H.Juni Sjafrien. Pemberantasan Tindak Pidana Korupsi. Jakarta: Fokus Media, 2008.

Jane, Elliott. Using Narrative in Social Research: Qualitative and Quantitative Approaches. London: Sage Publication Ltd, 2005.

Junius Nge, Herri. “Oligarki Partai Politik Dalam Rekrutmencalon Kepala Daerah (Studi Kasus Munculnya Calon Tunggal Pada Pemilihan Kepala Daerah Kabupaten Landak Tahun 2017)." Jurnal Academia Praja 1, no. 1 (2018): 59-84. Kantaprawira, Rusdi. Sistem Politik Indonesia. Bandung: Sinar Baru Algesindo, 1985.

Kennedy, David. "Anarchism, Shooling, and Democratic Sensibility." Stud Philos Educ, 2016, 1-18.

LaPorte, Jody. "Foreign versus Domestic Bribery: Explaining Repression in Kleptocratic Regimes." Comparative Politics 50, no. 1 (October 2017): 83-102. Marzuki, Peter Mahmud. Penelitian Hukum. Jakarta: Prenada Media Group, 2011. Muhammadiyah dan Nahdaltul Ulama (NU). Korupsi Itu Kafir. Jakarta: Mizan, 2010.

Muhaki, M. “Problem Delik Korupsi Dalam Hukum Pidana Islam." Jurnal Studi Islam: Pancawahana 12, no. 2 (2017): 22-38.

Pardede, Marulak. “Aspek Hukum Pemberantasan Tindak Pidana Korupsi Oleh Korporasi Dalam Bidang Perpajakan (Legal Aspect of Eradication Of Corruption Criminal Act In Taxation)." Jurnal Penelitian Hukum De Jure 20, no. 3 (2020): 335-61.

Pardo, Italo. "Who Is Corrupt? Anthropological Reflections On The Moral, The Criminal And The Borderline." Human Affairs 23 (2013): 124-47. 
Anita Marwing, Indonesian Political Kleptocracy and Oligarchy: A Critical Review ...

Samsuddin, Haris, Cakti Indra Gunawan, and Cahyo Sasmito. "Membongkar Relasi Kekuasaan Oligarki di Kota Batu: Studi Kasus Penyalahgunaan Kekuasaan Dalam Pemberian Keringanan Pajak Dan Korupsi Kebijakan Pt Bwr." Jurnal Ilmu Administrasi XVI, no. 2 (2019): 210-27.

Santoso, Listiyono, Dewi Meyriswati, and Ilham Nur Alfian. "Korupsi Dan Mentalitas: Kendala Kultural Dalam Pemberantasan Korupsi Di Indonesia." Masyarakat, Kebudayaan Dan Politik 27, no. 4 (2014): 173-83.

Satriajaya, Johan, Lilik Handajani, and I Nyoman Nugraha Ardana Putra. “Turbulensi Dan Legalisasi Kleptokrasi Dalam Pengelolaan Keuangan Desa." Jurnal Akuntansi Multiparadigma JAMAL 8, no. 2 (2017): 227-429.

Simarmata, Markus H. Peranan. "E-Government Dan Media Sosial Untuk Mewujudkan Budaya Transparansi Dan Pemberantasan Korupsi." Jurnal Integritas KPK 3, no. 2 (2017): 203-29.

Suryani, Ita. "Peran Media Iklan Televisi Sebagai Media Kritik Kasus Korupsi (Studi Kasus Pada Iklan Konten Djarum 76 Versi Kontes Jin)." Jurnal Komunikasi 9, no. 2 (2015).

Wahid, Abdul. "Kolaborasi Kleptokrasi Birokrasi Dan Korporasi." Jurnal Yurispunden 1, no. 1 (2018): 1-16.

Warf, Barney. "Global Geographies of Corruption." GeoJournal 81, no. 5 (2016): 657-69.

Wolf, Mark L. "The World Needs an International Anti-Corruption Court." Daedalus 147, no. 3 (2018): 144-56.

Yuhermansyah, E., and Z. Fariza. "Pidana Mati Dalam Undang-Undang Tindak Pidana Korupsi (Kajian Teori Zawajir Dan Jawabir)." Legitimasi: Jurnal Hukum Pidana Dan Politik Hukum 6, no. 1 (2017): 156-74. 